\title{
Thanh, Yasuko. (2019). Mistakes to Run With. Toronto: Hamish Hamilton.
}

\author{
Reviewed by: Mallory Garden, MacEwan University
}

Yasuko Thanh's memoir, "Mistakes to Run With" is the recounting of the unfortunate events that the author endured throughout her teenage years and in her early adult life. Thanh tells the story about her experience with a less-than-loving childhood, the sex trade, falling in love at a young age, substance abuse, the law and the difficulties that come with family life and children. Thanh writes this memoir as a parallel to the Buddhist Eighteen Levels of Hell, which she has cleverly named each chapter after. The book is separated into three larger parts and each part focuses on a significant shift in her life. Not only does Thanh tell her story, but she allows the reader to ponder on miniscule details, making the book specific enough to understand, but in a way that allows room for interpretation.

Mental illness is a theme in this book and Thanh's story that has the tendency to steer events in different directions. Thanh was diagnosed with borderline personality disorder, or BPD, at a very young age. This book exhibits the struggles of mental illness as a whole, including BPD, in a way that is enticing to the reader, while still bringing awareness to the negative impact that it can have on an individual and their relationships. She first shows symptoms of her mental illness when only a child, crying herself to sleep and showing early evidence and foreshadowing of selfharming. This is a theme that occurs throughout the entirety of the book, as she engages in several 
different forms of self-harm. She uses drugs, cuts herself (even through pregnancy), burns herself, and in her early years, she would eat old food to make herself sick or draw cuts on her dolls. She also engages in activities that more commonly reflect maladaptive societal behaviours, such as shoplifting, fighting, and working in the sex trade. In addition to many different forms of selfharm, there are several instances where she speaks of death in a comfortable and familiar way. Again, this first occurs in her childhood, saying to herself, "if I were dead, then they'd see" (p. 31), referring to her parents and their ignorance to her state of mind. In addition, towards the end of the memoir, it is revealed that Thanh has a condition called eosinophilia, and this new diagnosis brought her emotionally closer to the idea of death, as she begins researching ways to commit suicide (p. 247).

Mental illness was not only pervasive within Thanh and her own life, but also in other people involved in the story. Thanh's parents were distant in her younger years, and generally, neither parent demonstrated their love in the way she needed as a child. Thanh recalls instances where her father would malinger and claim that their neighbour was wanting to kill him, along with his doctors (p. 29). This could reflect Thanh's interpretation of her father's mental illness, or it could be only scratching the surface as to how he would really behave around his children, allowing room for the reader to explore the topic further on their own. Furthermore, an incident in which another sex worker commits suicide by jumping off a balcony in front of several people, including Thanh herself (pp. 110-111) may have been the start of a change of heart for Thanh and her life decisions. A love interest of Thanh's after her time in the sex trade, Kyle, also has severe bipolar disorder and paranoia. Thanh understands the struggle of mental illness and sympathizes with Kyle and his actions during his paranoid episodes, until he became a toxic presence in her life 
at which point, she left. Overall, the theme of mental illness is a strong aspect of this book, and it is evident that the impact of mental illness guided Thanh's life from the beginning and continued to do so throughout challenges she faced.

Religious beliefs are an evidently important part of Thanh's life while she was growing up. Thanh found solace in her religion being that she would read bible verses frequently, and when she felt unloved by her parents, she turned to God to seek comfort (p. 24). She loses her faith throughout the first few chapters of the book before the inevitable drift from her family life. Her descent into sex work and her departure from her home are aggravating factors in this, and the first time Thanh defied God was when she was only fourteen years old. She insisted on listening to rock music, and after doing so, claimed that "if God was against listening to the Beatles, then I was against God" (pp. 39-40). Throughout her teen and early adult years, she strayed further away from her religion, and towards the end of the book, her path to self-discovery longs for the kind of devotion that comes with religion (p. 191). Later in her life, Thanh went on to write a personal essay about her defiance from her Christian beliefs (p. 205), which can tell readers that her faith hadn't returned to her at the time of writing the memoir and had shown no evidence that it would return.

Throughout the book, a common theme that Thanh demonstrates and was relevant throughout her life was a longing for love and acceptance. Thanh often somberly describes her relationships with tricks (clients in the sex trade), love interests, friends, and her family in a way that can be relatable to the reader, even in the most different of cases. Throughout Thanh's childhood, her parents were heavily involved with her younger brother, David. This left Thanh in 
a susceptible position where she felt as though she could not express emotion or vulnerability she says early in the book about her household, "voicing unpleasant emotions made you unlovable" (p. 7). She felt repressed her whole childhood, and as a result, began acting out on these repressed feelings, leading to the need for acceptance. To begin with, Thanh struggled with controlling emotions and she began to refer to her early love interests as "boyfriend-to-be" or "lover" (pp. 5556), when they were only present in her life for a fleeting moment. One of the most memorable quotes from the memoir stems from her inability to hide her helplessness and desperation for acceptance: "[m]y need for love made me exploitable" (p. 60). This idea spans across the whole book when considering her relationships with Jay, but especially her relationship with Avery. Avery would use Thanh for extra income as a pimp, as well as keeping her around for his own purposes. She was only sixteen years old when she crossed paths with Avery, indicating that he was extremely exploitive of her because of her age. While exploitation was undoubtedly a large part of Thanh's life being in the sex trade, it can be argued that she was more affected by the exploitation she faced in her personal relationships which is demonstrated through her choice to write about these more than her experiences at work.

Overall, Yasuko Thanh wrote an excellent memoir about her life as a sex worker, drug user, teenager, daughter, and mother. I believe that the intention behind the writing of this book is to not only bring awareness to the issue of teenaged sex workers fending for themselves in a dangerous society, but also to inspire those that might be going through a similar situation. Thanh is creative in her way of writing and allows for readers to use their imagination, while still being candid and transparent about difficult topics. A specific aspect of the book that I admired was that 
Thanh did not write an elaborate 'feel-good' ending. She used roughly equal space speaking about the negative events as the positive events. This makes for a more refreshing and balanced approach. An improvement I can suggest is that the timeline of the book leaves room for confusion. Thanh jumps backwards and forwards in time, leaving the timeline scattered and hard to follow. The best academic audience for this memoir is anyone interested in raising awareness about sex work, assault, and the importance of a family that is present in a child's life. This audience can include students, women's rights activists, educators, or even politicians that hope to make a change. There are also important sociological implications that accompany this book, such as the breakdown of the family home, as well as the long-term psychological effects that this can have on an individual. Therefore, from an academic perspective, both sociologists and psychologists may be interested in reading this memoir. Yasuko Thanh is an inspiring woman and has overcome adversity with grace, and any reader will be proud to reach the end of this story. 